\title{
Effect of Paraquat Herbicide on Oxidative Stress Biomaker Enzyme Activities in C. Gariepinus
}

\author{
${ }^{1}$ Nafi'u, S. A., ${ }^{2}$ Suleiman, K., ${ }^{3}$ Ahmad, M. K and ${ }^{4}$ Zakariyya, M \\ ${ }^{1}$ Department of Science Laboratory Technology, \\ Kano State Polytechnic, \\ Kano, Nigeria \\ ${ }^{2}$ Department of Biological Sciences, \\ Bayero University, \\ Kano \\ ${ }^{3}$ Department of Animal Sciences, \\ Federal University Kashere, \\ Gombe State, Nigeria \\ ${ }^{4}$ Departmental Environmental Management, \\ Bayero University, Kano
}

Email: nafiune.sn@gmail.com

\begin{abstract}
Toxicity assessment was conducted for 96hr exposure duration using synthetic herbicide (paraquat dichloride $276 \mathrm{~g} / \mathrm{L}$ ) on Claris gariepinus with mean weight range of $27.2-29.7 \mathrm{~g}$ and mean length $10.95-15.5 \mathrm{~cm}$. They were exposed to varying herbicide concentrations of 0.0, 3.45, 6.90, 10.35 and $13.5 \mathrm{mg} / \mathrm{L}$ with 5-levels exposure concentrations in a Completely Randomized Design (CRD). Liver, gills and kidney tissues were analyzed for oxidative stress enzymes activities using Solarbio science assay kit (BC1170, 0170 and 0020). Four days lethal concentration $\left(L C_{50}\right)$ value for $96 \mathrm{hr}$ was found to be $7.298 \mathrm{mg} / \mathrm{L}$. The treated fish displayed erratic swimming with irregular opercular movement, loss of reflex, mucus secretion and increased air gulping with the increasing concentration of the herbicide compared with the control fish. Antioxidant biomarkers activities revealed that Glutathione S-transferase (GST), catalase (CAT) and superoxide dismutase (SOD) activities increased significantly $(P<0.05)$ in the gills, liver and kidney tissues at higher concentrations compared with control. It can be deduced that alterations in the oxidative stress enzyme activities in the exposed fish to paraquat exert toxic effect on the liver, gills and kidney tissues. It is therefore recommended that appropriate authorities should develop strategies on minimizing the indiscriminate use of synthetic herbicides due to their impact on aquatic biota such as fish in order to reduce its potential risk to other non-target organisms.
\end{abstract}

Keywords: Clarias gariepinus, Lethal concentration, Oxidative Stress enzymes, Paraquat, Toxicity assessment

\section{INTRODUCTION}

Herbicides are mixtures of substances designed to regulate the growth of undesirable broadleaved weeds and grasses (Bartosz et al., 2018). They are applied by farmers during 
agricultural production to facilitate crop productivity (Ayanda et al., 2018). They include broad classes of pesticides with more than 300 active formulations in several commercial compositions (Annett et al., 2014). Most herbicides used in farming activities reach aquatic ecosystem via many routes. They can be detected far from their sources of origin due to their persistency in nature, long-range transport through atmospheric exchange, water currents, debris, animal migration and other anthropogenic misapplication (e.g. pouring away spray leftovers and sprayer washing (Ogamba et al., 2014).

Paraquat, is a nitrogen based nonselective and contact herbicide applied in the control of unwanted grasses (Edori et al., 2014). It is among the most widely used herbicides by farmers and sold in over 130 countries. It readily dissolves and dissociates in aqueous solutions while in contact with soil is rapidly absorbed, combine to the soil particles and leached to the aquatic domain and get easily concentrate by aquatic biota, including fish (Ogamba et al., 2014). Paraquat interfere with intracellular electron transfer systems of free radicals in plants causing cellular damage. It has been recorded in many aquatic ecosystems worldwide (Oluwatosin et al., 2016). Edori et al. (2013) and Nwani et al. (2015) reported alterations in electrolyte concentration and physiological impairment in Clarias gariepinus exposed to paraquat. Contaminants in the environment like heavy metals and herbicides have been recorded in modulating antioxidant defense systems thereby causing oxidative damage in aquatic biota through the generation of Reactive Oxygen Species (ROS) (Ani et al., 2017).

Oxidative stress is a condition attributed with an increased rate of cellular damage induced by oxygen free radicals and other reactive oxygen species (Ullah et al., 2019). It results from an imbalance between pro-oxidant and antioxidant in favour of pro-oxidant, this is due to the free radicals' activities in facilitating various physiological activities in aquatic biota such as transcriptional pathways in a cell (Nwani et al., 2015). Antioxidant defense enzymes activities is a significant bioindicator of environmental pollution prior to oxidative damage in aquatic biota (Ada et al., 2012). Antioxidant defense enzymes of the fish induce oxidative stress, generates free radicals and accumulate reactive oxygen species (ROS) (Akinwande et al., 2016). Therefore, prolonged exposure of fish to pesticides causes oxidative damage to biological molecules, such as protein and DNA damage (Modesto and Martinez, 2010). Fish developed defensive system enzymes to counter the effect of ROS arising from the catalysis of xenobiotics. The enzymes responsible in detoxification of ROS in an organism are superoxide dismutase (SOD), catalase (CAT), glutathione transference (GST) and glutathione reductace (GSH). Under oxidative stress, these enzymes become easily inducible, indicating their ability to adapt to stress conditions (Nwani et al., 2015). In view of the foregoing this research aimed at assessing oxidative stress response in tissues of African catfish exposed to Paraquat herbicide. This will go a long way to facilitate agro-chemical producers in developing easily biodegradable herbicides without detrimental effect on nontarget organisms such as fish. Hence, the healthy catfish for consumption and among other uses will be sustained.

\section{MATERIALS AND METHODS \\ Source of Experimental Fishes}

A total of 280 healthy post juvenile experimental fish (C. gariepinus) with mean weight range of $124.7-176.8 \mathrm{~g}$ and mean length $31.9-37.3 \mathrm{~cm}$ were procured from Dalar Kifi Fish Farm, Langel Town along Gwarzo Road, Kano State, Nigeria located between latitude $12^{\circ} 40^{\circ}-10^{\circ}$ $30^{\circ}$ and longitude $7{ }^{\circ} 40^{\circ}-9 \circ 40^{\circ}$. The fish were maintained in a dark plastic tank (500L), filled with dechlorinated water and renewed daily. They were acclimatized at $27^{\circ} \mathrm{C}$ and relative 
humidity (38\%), for 7 days in aquarium at Biological Sciences Department, Bayero University, Kano. They were fed twice with pellet diet containing $42 \%$ crude proteins with $3 \mathrm{~mm}$ in size produced by Bluecrown fish feed Nigeria. However, feeding was terminated $24 \mathrm{~h}$ prior to toxicity test as adopted by Ezike et al. (2019). A $72 \mathrm{~h}$ range finding test was initially conducted before the acute toxicity test to ascertain the range concentrations of the herbicide for definitive test.

\section{Water Quality Parameters Analysis}

Water quality parameters were determined before the acute toxicity test using multifunction water testing kit (Model no. EZ-9909-SP). Parameters such as pH and Dissolved oxygen, Electrical Conductivity, water temperature and Total Dissolved Solids were determined as described by APHA (2005).

\section{Source of Test Chemical}

Paraquat Dichloride (ParaeForce) with 276g/L was purchased from registered store at Sabongari market, Kano with Batch No: 20190710 and NAFDAC Reg: A5-0109 manufactured by Nanjing Redsun Biochemistry Co. Ltd., Nanjing City, China. Marketed by Jubail Agro Tec., Kano, Nigeria

\section{Experimental Design}

Fish samples were subjected to Completely Randomized Design (CRD) using GenSta version 2.4 with 5 (five) levels exposure concentrations was prepared as adopted by Akinrotimi et al. (2013). A set of ten fishes with five (5) treatments and three replications were randomly exposed to paraquat making a total of fifteen experimental units. One treatment with a set of 10 fish was maintained in water, without the test chemicals, which served as a control.

\section{Acute Toxicity Test}

The acute toxicity test to determine the $96 \mathrm{~h} \mathrm{CC}_{50}$ values for paraquat was carried out in static renewal system (complete replacement of test water after every 24 hours) using $50 \times 80 \times 50$ $\mathrm{cm}$ plastic containers (100L) containing 40L of borehole water. The experiment was carried out according to the procedure described by OECD (2014). Paraquat concentration at 0.0 (control) $0.5,1.0,1.5$ and $2.0 \mathrm{ml} / \mathrm{L}$ was converted to $0.0,3.45,6.90,10.35$ and $13.5 \mathrm{mg} / \mathrm{L}$. This aimed at determining the definitive concentration of the herbicide as described by Akinwande et al. (2016). The conversion and dilution for range finding test was carried out using formula described by Fayinminmu et al. (2017). The formula is illustrated as follows:

$$
\mathrm{C}_{1} \mathrm{~V}_{1}=\mathrm{C}_{2} \mathrm{~V}_{2}
$$

Where $\mathrm{C}_{1}=$ initial concentration of stock solution $(\mathrm{g} / \mathrm{L})$

$\mathrm{V}_{1}=$ volume of stock used $(\mathrm{ml})$

$\mathrm{C}_{2}=$ desired concentration $(\mathrm{g} / \mathrm{L})$

$\mathrm{V}_{2}=$ required volume of water for dilution $(\mathrm{ml})$

Therefore, forty liters (40L) of dechlorinated water was poured into each container, while $0.5,1.0,1.5$ and $2.0 \mathrm{ml}$ of water was removed and replaced with equal volume of paraquat from the stock solution. The fish was starved for 24 hours prior to acute toxicity test. The rate of mortality was assessed and recorded to avoid possible deterioration of the water quality.

\section{Observation of Behavioural Responses}

The visual observation was carried out after each exposure for the period of thirty (30) minutes to record response such as erratic swimming, air gulping, lost of reflex, mucous 
secretion and opercular movement shown by the fish according to Nwani et al. (2013) and Rakesh and Kumar (2019). Fish was considered dead when there is no sign of opercular movement or no response to gentle prodding.

\section{Oxidative Stress Enzymes Analysis}

The enzyme's activities of CAT, SOD and GST were carried out at Biochemistry Laboratory, Bayero University, Kano using the Solarbio science assay kit (BC1170, 0170 and 0020). The liver, kidney and gills of the fish were washed in ice cold buffer. The tissues were rinsed to remove blood stained with cold isolation buffer, containing $100 \mathrm{mMTris}-\mathrm{HCl}$ at $\mathrm{pH}$ of 7.20 and homogenized on ice in homogenizing container with a motar and a pestle. The homogenate was centrifuged at 10000rpm for 8 minutes.

\section{Catalase Activity}

The catalase (CAT) activity was determined using the method adopted by Oluwatosin et al. (2016) using the Solarbio Life science CAT kit (Cat No. BC0020). Exactly 150 $\mu$ l of tissues (liver, gill and kidney) homogenate was added to a $10 \mathrm{ml}$ test tube containing $3.0 \mathrm{ml}$ of $50 \mathrm{mM}$ potassium phosphate buffer $(\mathrm{pH} 7.0)$. The reaction was initiated by adding $1 \mathrm{ml}$ of $30 \mathrm{mM}$ $\mathrm{H}_{2} \mathrm{O}_{2}$ and results in absorbance was recorded after every 30 seconds at $570 \mathrm{~nm}$ in a double beam spectrophotometer (IL251 model).

\section{Glutathione S-transferase (GST) Activity}

Glutathione $S$-transferase (GST) activity was conducted as using the Solarbio Life science GST kit (Cat No. BC1170) as described by the manufacturer. Exactly $1 \mathrm{ml}$ of the sample homogenate was added to the reaction mixture as conjugant with $30.73 \mathrm{mg}$ reduced glutathione $(0.1 \mathrm{M})$ dissolved in $1 \mathrm{ml}$ of $0.1 \mathrm{M}$ phosphate buffer $(\mathrm{pH} 6.5)$. Later, $4.96 \mathrm{~g}$ of dipotassium hydrogen phosphate and $9.73 \mathrm{~g}$ of potassium dihydrogen phosphate was added to the mixture to make it 1litre. This results in a shift of its absorption maximum to $450 \mathrm{~nm}$ and increases to $520 \mathrm{~nm}$ to provide a direct measurement of enzymatic for reaction.

\section{Superoxide Dismutase (SOD)}

Activity Superoxide dismutase enzymes were determined using the Solarbio Life science SOD kit (Cat No. BC0170). The procedure described by the manufacturer involved addition of $1 \mathrm{ml}$ extraction reagent to $0.1 \mathrm{~g}$ tissue sample (liver, gills and kidney) and homogenized on ice bath. The supernatant was collected by centrifuging at $8000 \mathrm{rpm}, 4^{\circ} \mathrm{C}$, for 10 minutes. Exactly $90 \mu \mathrm{L}$ of the mixture was collected in a glass cuvette during which $240 \mu \mathrm{L}$ of reagent I, $6 \mu \mathrm{L}$ of reagent II, $30 \mu \mathrm{L}$ of reagent $\mathrm{V}$ and $180 \mu \mathrm{L}$ of reagent III were added and mix carefully. This was followed by adding $480 \mu \mathrm{L}$ of distilled water and allowed for 30minutes at $4^{\circ} \mathrm{C}$. The absorbance was measured using spectrophotometer (IL251 model) at 560 $\mathrm{nm}$ as described by Nahed (2011).

\section{Statistical Analyses}

Probit analysis was used to determine the mortality profile $\left(\mathrm{LC}_{50}\right)$ of the experimental fish using SPSS version 20.0. One-way Analysis of Variance (ANOVA) was used to determine the effect of varying pesticide concentrations on the oxidative stress enzymes activity in $C$. gariepinus. Duncan Multiple Range Test at 5\% probability level was used to compare the means.

\section{RESULTS}


Table 1, revealed the range values of the physicochemical parameters of the experimental water. DO, TDS, EC, pH turbidity and temperature ranged between 5.31-6.57 mg/L, 173-321 $\mathrm{mg} / \mathrm{L}, 318-431 \mu \mathrm{S} / \mathrm{cm}, 7.72-8.71,21-37 \mathrm{NTU}$ and $27.4-32.1^{\circ} \mathrm{C}$ respectively.

Table 1: The Physico-chemical Parameters of the Experimental Water Exposed with Paraquat

\begin{tabular}{lcll}
\hline Parameter & Range & Mean $( \pm \mathrm{SD})$ & \multicolumn{1}{c}{ Standard limits } \\
\hline Water temperature $\left({ }^{\circ} \mathrm{C}\right)$ & $27.4-32.1$ & $29.2 \pm 0.48$ & $<40^{\circ} \mathrm{Cmg} / \mathrm{L}^{*}$ \\
DO $(\mathrm{mg} / \mathrm{L})$ & $5.31-6.57$ & $5.5 \pm 0.61$ & $5.0-9.0 \mathrm{mg} / \mathrm{L}^{* *}$ \\
$\mathrm{TDS}(\mathrm{mg} / \mathrm{L})$ & $173-321$ & $351 \pm 2.06$ & $500 \mathrm{mg} / \mathrm{L}^{* *}$ \\
E.C $(\mu \mathrm{S} / \mathrm{cm})$ & $318-431$ & $372 \pm 0.99$ & $1000 \mu \mathrm{S} / \mathrm{cm}^{* *}$ \\
Turbidity $(\mathrm{NTU})$ & $21-37$ & $27.1 \pm 1.23$ & $25 \mathrm{NTU}{ }^{* *}$ \\
pH & $7.72-8.71$ & $8.21 \pm 1.02$ & $6.0-9.0^{*}$ \\
\hline${ }^{*} \mathrm{FME}(2001),{ }^{* *} \mathrm{FAO} / \mathrm{WHO}(2018)$ & &
\end{tabular}

Table 2 revealed the behavioral alterations examined in various concentrations in the exposed fish as well as in the control treatments. Normal swimming behaviour was observed in the control concentrations throughout the exposure duration. In treatment with higher concentration of 10.35 and $13.5 \mathrm{mg} / \mathrm{L}$, the fish swam erratically, with an increase in opercular movement. By exposure duration increase $(72-96 \mathrm{hr})$, swimming rate declined greatly and experimental fish at 10.35 and $13.5 \mathrm{mg} / \mathrm{L}$ lost reflex (balance). By 96hr examination, fish in the highest concentrations of 13.5, developed an increase in air gulping, they became motionless and decreased opercular movement. They eventually settled down at the bottom of the container with the operculum wide opened and died.

Table 2: Behavioral Changes Observed by Clarias gariepinus at Period of 96hr Exposure to Paraquat

\begin{tabular}{|c|c|c|c|c|c|c|c|}
\hline $\begin{array}{l}\text { Exposure } \\
\text { time (hr) }\end{array}$ & $\begin{array}{l}\text { Concentration } \\
(\mathrm{mg} / \mathrm{L})\end{array}$ & $\begin{array}{l}\text { Air } \\
\text { gulping }\end{array}$ & $\begin{array}{l}\text { Erratic } \\
\text { swimming }\end{array}$ & $\begin{array}{l}\text { Lost } \\
\text { reflex }\end{array}$ & of & $\begin{array}{l}\text { Mucus } \\
\text { secretion }\end{array}$ & $\begin{array}{l}\text { Opercular } \\
\text { movement }\end{array}$ \\
\hline & 0.00 & - & - & - & & - & +++ \\
\hline & 4.50 & - & - & - & & - & ++ \\
\hline \multirow[t]{3}{*}{12} & 6.90 & - & - & - & & + & + \\
\hline & 10.5 & - & - & - & & + & ++ \\
\hline & 13.5 & ++ & + & + & & ++ & ++ \\
\hline \multirow[t]{5}{*}{48} & 0.00 & - & - & - & & - & - \\
\hline & 4.50 & - & + & + & & + & + \\
\hline & 6.90 & - & - & + & & + & + \\
\hline & 10.5 & - & + & + & & + & + \\
\hline & 13.5 & +++ & + & ++ & & ++ & - \\
\hline \multirow[t]{5}{*}{72} & 0.00 & - & - & - & & - & - \\
\hline & 4.50 & + & - & + & & - & + \\
\hline & 6.90 & - & - & + & & + & + \\
\hline & 10.5 & + & + & + & & + & + \\
\hline & 13.5 & ++ & - & ++ & & - & - \\
\hline \multirow[t]{5}{*}{96} & 0.00 & + & - & - & & - & - \\
\hline & 4.50 & + & - & + & & - & - \\
\hline & 6.90 & ++ & + & + & & + & - \\
\hline & 10.5 & ++ & + & + & & + & - \\
\hline & 13.5 & +++ & +++ & +++ & & ++ & - \\
\hline
\end{tabular}

Key: =none - , mild + , moderate ++ , Strong $+++\quad$ adopted from Ani et al. (2017)

Mortality profile revealed an increase with increasing concentrations and exposure duration and the highest mortality rate was obtained in the highest concentrations. The mortality 
corresponding to each concentration and the percentage survival are presented in Figure 1. Paraquat $96 \mathrm{hr} \mathrm{LC}_{50}$ values assessed based on the transformed probit analysis was $7.298 \mathrm{mg} / \mathrm{L}$. Linear relationship between the probit mortality and the concentration of the herbicides revealed positive correlation of $\mathrm{r}^{2}=0.9918$, indicating that mortality of the fish increased as the concentration of the herbicide also increased.

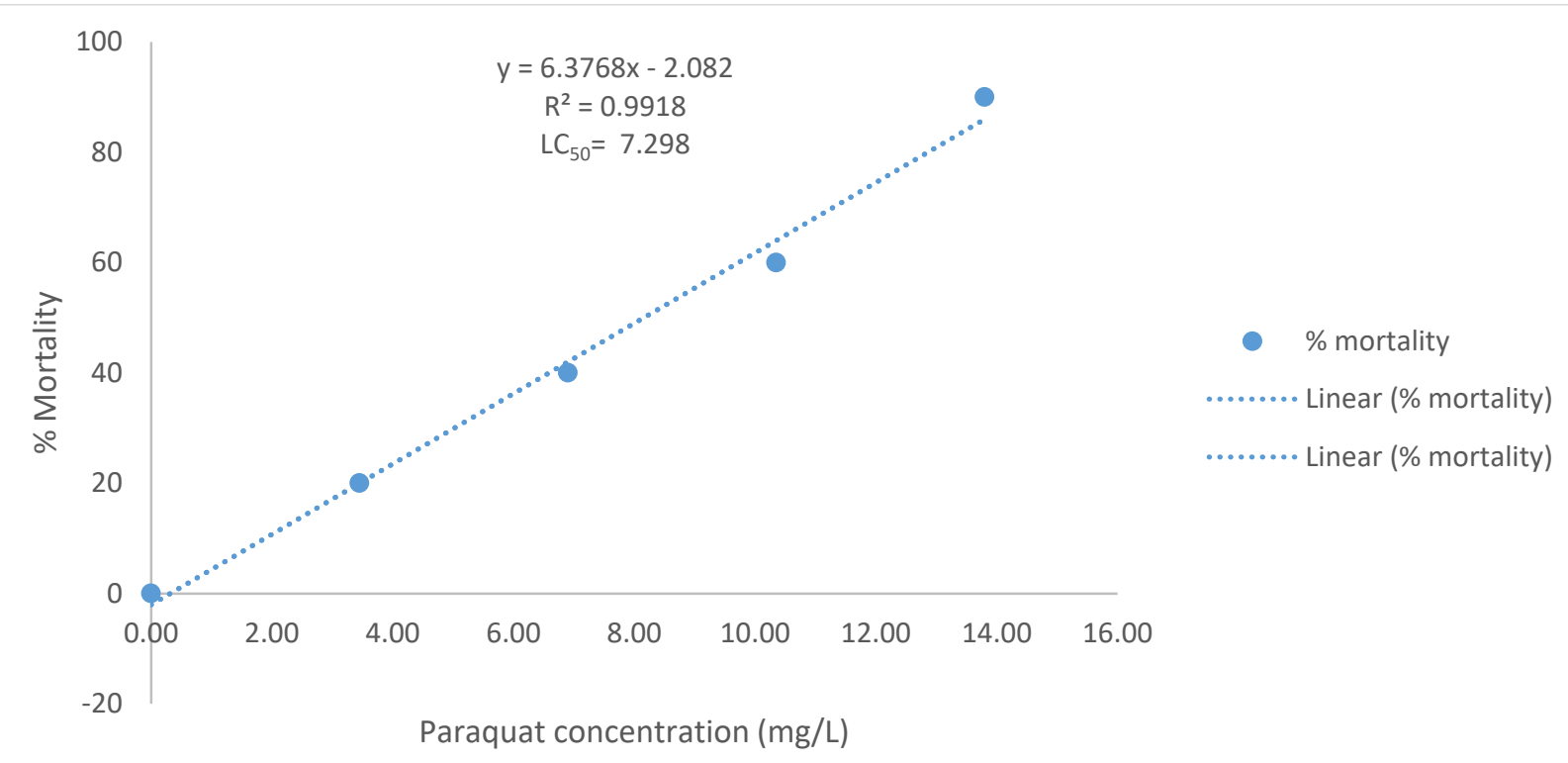

Fig 1: Mortality Profile (\%) of C. gariepinus Exposed with Different Paraquat Concentrations at 96hr Exposure Duration

Table 3, indicates fish survival and percentage mortality at different treatment concentrations in the fish exposed to Paraquat. The number of survived and dead fish were observed depending on the exposure duration of 24, 48, 72 and 96hr in Clarias gariepinus. Paraquat concentration of $13.5 \mathrm{mg} / \mathrm{L}$ indicates the highest fish mortality of $90 \%$ and lowest survival of $10 \%$ while no mortality was observed in the control throughout the exposure duration (Table 3).

Table 3: Percentage Mortality of $C$. gariepinus Exposed to Different Concentrations of Paraquat

\begin{tabular}{|c|c|c|c|c|c|c|c|c|c|}
\hline \multirow[t]{2}{*}{$\begin{array}{l}\text { Exposed } \\
\text { conc.(mg/L) }\end{array}$} & \multirow[t]{2}{*}{$\begin{array}{l}\text { log } \\
\text { conc. } \\
(\mathrm{mg} / \mathrm{L})\end{array}$} & \multirow[t]{2}{*}{$\begin{array}{l}\text { No. of } \\
\text { exposed } \\
\text { fish }\end{array}$} & \multicolumn{4}{|c|}{$\begin{array}{l}\text { No. of live fish at different } \\
\text { duration (hours) }\end{array}$} & \multirow[t]{2}{*}{$\begin{array}{l}\% \\
\text { survival }\end{array}$} & \multirow[t]{2}{*}{$\begin{array}{l}\% \\
\text { mortality }\end{array}$} & \multirow[t]{2}{*}{ Probit } \\
\hline & & & 24 & 48 & 72 & 96 & & & \\
\hline 0 & & 10 & 0 & 0 & 0 & 0 & 100 & 0 & \\
\hline 4.50 & 0.653 & 10 & 0 & 0 & 1 & 1 & 80 & 20 & 4.16 \\
\hline 6.90 & 0.838 & 10 & 0 & 1 & 2 & 1 & 60 & 40 & 4.75 \\
\hline 10.5 & 1.021 & 10 & 1 & 1 & 2 & 2 & 40 & 60 & 5.25 \\
\hline 13.5 & 1.130 & 10 & 0 & 2 & 3 & 4 & 10 & 90 & 6.28 \\
\hline
\end{tabular}

\section{Oxidative Stress Enzymes Activity}

Findings in oxidative stress enzyme activities of CAT, SOD and GST examined after acute exposure of post juveniles C. gariepinus to paraquat are presented in Table in 4. Superoxide Dismutase (SOD) Activity had significant difference decreased $(p<0.05)$ between the treatments and control samples in gills, kidney and liver tissues. Liver tissue control sample had a lower mean SOD activity of $1.79 \mathrm{Unit} / \mathrm{mg}$ prot while the significant higher mean value of $4.16 \mathrm{Unit} / \mathrm{mg}$ prot was recorded from fishes treated with the highest paraquat 
concentrations of $13.5 \mathrm{mg} / \mathrm{L}$. There was significant increased $(\mathrm{p}<0.05)$ in SOD activity in the kidney (1.19 Unit/mg prot) and gills tissues (5.13Unit/mg prot) of the exposed fish at the highest concentrations of $13.5 \mathrm{mg} / \mathrm{L}$ compared with the respective control values of 2.47 and $3.35 \mathrm{unit} / \mathrm{mg}$ prot respectively (Table 4 ).

Catalase activity decreased significantly $(\mathrm{P}<0.05)$ from $74.18-46.21 \mathrm{nmol} / \mathrm{min} / \mathrm{mg}$ prot between the highest concentrations and control $13.5 \mathrm{mg} / \mathrm{L}$ in the liver sample. CAT activity differed significantly $(\mathrm{P}<0.05)$ in gills and kidney tissues between the highest concentrations the control from 89.1-52.78 and 71.78-42.92 $\mathrm{nmol} / \mathrm{min} / \mathrm{mg}$ prot. (Table 4).

There was significantly higher GST activity $(\mathrm{P}<0.05)$ in the liver and gills tissues exposed to the highest concentrations $(13.5 \mathrm{mg} / \mathrm{L})$ with $45.20 \mathrm{nmol} / \mathrm{min} / \mathrm{mg}$ prot and $54.31 \mathrm{nmol} / \mathrm{min} / \mathrm{mg}$ while the lowest activity of $36.80 \mathrm{nmol} / \mathrm{min} / \mathrm{mg}$ prot was obtained in the kidney tissue. GST had its lowest activity in the liver, gills and kidney tissues at the respective controls of $36.98,39.15$ and $23.60 \mathrm{nmol} / \mathrm{min} / \mathrm{mg}$ prot. (Table 4). Comparing with the control, there were significant increase in the activities of all the oxidative stress enzymes activities in the tissues after $96 \mathrm{~h}$ and the increases were also concentration dependent.

Table 4: Oxidative Stress Enzymes Activity in C. gariepinus Exposed to Paraquat

\begin{tabular}{lllll}
\hline concentration & $(\mathrm{mg} / \mathrm{L})$ & SOD (unit/ mg prot.) & CAT (Unit/mg prot.) & GST (nmol/min/mg prot) \\
\hline \multirow{2}{*}{ Liver } & 0 & $2.16 \pm 1.02^{\mathrm{a}, \mathrm{b}}$ & $46.21 \pm 0.92^{\mathrm{a}, \mathrm{b}}$ & $36.98 \pm 0.01^{\mathrm{b}}$ \\
& 4.5 & $2.71 \pm 0.09^{\mathrm{a}}$ & $45.06 \pm 0.13^{\mathrm{b}}$ & $39.71 \pm 1.01^{\mathrm{a}, \mathrm{b}}$ \\
& 6.9 & $3.31 \pm 1.00^{\mathrm{a}}$ & $61.18 \pm 0.03^{\mathrm{b}}$ & $41.90 \pm 0.17^{\mathrm{a}}$ \\
& 10.5 & $3.71 \pm 0.01^{\mathrm{b}}$ & $71.50 \pm 0.07^{\mathrm{a}, \mathrm{b}}$ & $43.68 \pm 0.02^{\mathrm{a}}$ \\
& 13.5 & $4.79 \pm 0.01^{\mathrm{a}, \mathrm{b}}$ & $74.18 \pm 0.01^{\mathrm{a}, \mathrm{b}}$ & $45.20 \pm 0.10^{\mathrm{b}}$ \\
Gills & 0 & $3.35 \pm 0.10^{\mathrm{b}}$ & $52.78 \pm 0.07^{\mathrm{b}}$ & $39.15 \pm 0.21^{\mathrm{a}, \mathrm{b}}$ \\
& 4.5 & $3.57 \pm 0.00^{\mathrm{a}, \mathrm{b}}$ & $75.11 \pm 0.16^{\mathrm{a}}$ & $47.21 \pm 0.16^{\mathrm{b}}$ \\
& 6.9 & $4.38 \pm 0.34^{\mathrm{a}, \mathrm{b}}$ & $69.01 \pm 0.10^{\mathrm{a}}$ & $53.78 \pm 1.00^{\mathrm{a}}$ \\
& 10.5 & $4.67 \pm 0.06^{\mathrm{a}}$ & $54.91 \pm 1.01^{\mathrm{a}, \mathrm{b}}$ & $53.96 \pm 0.61^{\mathrm{a}, \mathrm{b}}$ \\
& 13.5 & $5.13 \pm 0.03^{\mathrm{b}}$ & $89.10 \pm 0.01^{\mathrm{b}}$ & $54.31 \pm 0.10^{\mathrm{a}}$ \\
& 0 & $1.19 \pm 0.01^{\mathrm{a}}$ & $42.92 \pm 0.07^{\mathrm{a}, \mathrm{b}}$ & $23.60 \pm 1.01^{\mathrm{b}}$ \\
& 4.5 & $1.23 \pm 0.56^{\mathrm{a}, \mathrm{b}}$ & $57.31 \pm 0.01^{\mathrm{a}}$ & $32.27 \pm 0.23^{\mathrm{a}}$ \\
& 6.9 & $1.35 \pm 0.10^{\mathrm{a}}$ & $61.67 \pm 0.15^{\mathrm{a}}$ & $34.99 \pm 0.01^{\mathrm{a}}$ \\
& 10.5 & $1.72 \pm 0.31^{\mathrm{a}, \mathrm{b}}$ & $67.82 \pm 0.17^{\mathrm{b}}$ & $35.67 \pm 0.44^{\mathrm{a}}$ \\
& 13.5 & $2.47 \pm 0.01^{\mathrm{a}, \mathrm{b}}$ & $71.78 \pm 0.16^{\mathrm{a}, \mathrm{b}}$ & $36.80 \pm 1.56^{\mathrm{a}, \mathrm{b}}$ \\
\hline
\end{tabular}

Values are mean and SD. Mean values with different superscripts in a column are significantly different $(\mathrm{P}<0.05)$

\section{DISCUSSION}

Acute toxicity investigation is among the initial stage in water quality assessment requirements for aquaculture (Ani et al., 2017). The present findings revealed that exposure of the experimental fish to paraquat led to decrease in survival rate and an increased in mortality rate at various concentrations. Similar observation was reported by Ezike et al. (2019). During the 96hr exposure duration the experimental fish revealed varying stressful behaviour such as erratic swimming, lost of reflex and erratic swimming and decreased opercular movement. These changes were observed in the highest exposure treatment. Respiratory impairment and habitat alteration might be the cause of air gulping experienced 
by the experimental fish; or due to the effect of active ingredients in the herbicide to the fish's body physiology as observed by Ogamba et al. (2014). Mucus secretion examined in the treated fish may perhaps be due to the non-specific impact of the toxicants on the epidermal mucus layer in the fish body (Ezike et al., 2019). The secretion may also serve as barrier in reducing the herbicides' irritating effect on the fish's body as reported by EizadiMood et al. (2011).

Paraquat being a nitrogen based herbicides, has been reported to alter homeostasis and electron transfer machanism in fish (Akinsorontan et al., 2019). Altering the fish's homeostasis, during exposure to paraquat could be responsible for the lost of reflex observed in the experimental fish. Similar findings was recorded by Omoniyi et al. (2013) who recorded inconsistent jumping and respiratory distress among C. gariepinus exposed to dichlorvos. The observed changes in the normal behavior could be attributed to metabolic alterations in fish trying to cope with the toxic effect of paraquat (Aghoghovwia and Izah, 2018). The erratic swimming and faster opercular movement associated with the depletion of oxygen in the treated water leading to decline in carbohydrate metabolism making the fish difficult to cope with the water quality as reported by Mishra (2017). The behavioral changes recorded in the present study corroborates with the findings of Ani et al. (2017) on glyphosate.

The $\mathrm{LC}_{50}$ values depend on type and nature of fish species, varying chemistries of the compound forming the pesticide and the test condition (Arivu et al., 2016). After 96hr of exposure, the $\mathrm{LC}_{50}$ for paraquat was $7.298 \mathrm{mg} / \mathrm{L}$ which is lower than what was recorded of $0.07 \mathrm{mg} / \mathrm{L}$ by Ladipo et al. (2011), $0.007 \mathrm{~g} / \mathrm{L}$ by Ayanda et al. (2018) and $40.768 \mathrm{~g} / \mathrm{L}$ by Akinsorotan et al. (2019). The $96 \mathrm{hr} \mathrm{LC} \mathrm{L}_{50}$ obtained could be attributed to its bioaccumulation and biomagnification potential in fish tissues as reported by (Akinsorotan et al., 2019). The difference in the $\mathrm{LC}_{50}$ values obtained is associated with exposure duration, herbicides sensitivity and varying surfactants in the paraquat. It could also be due to the susceptibility shown by the exposed fish to the chemical (Ezenwosu et al., 2020). Variation in the $\mathrm{LC}_{50}$ could be due to physiological condition of the fish, size and age of the fish indicating that, many $\mathrm{LC}_{50}$ values can be obtained from the same herbicide/fish species (Ullah et al., 2019).

Oxidative stress is a condition resulting from imbalance between antioxidant/pro-oxidant (Ullah et al., 2019). Fish like any other organism develop antioxidant mechanism such as the use of CAT and SOD enzymes which are used to balance the damage by ROS (Annett et al., 2014). Paraquat have been reported to induce oxidative stress through changes in the antioxidant enzyme activities (Babatunde and Oladimeji, 2014). SOD is among the primary internal antioxidant enzymes present in the cell giving protection against oxidative stress (Hameed, 2015). It transformed superoxide radicals to $\mathrm{H}_{2} \mathrm{O}_{2}$, which eventually breakdown to harmless compounds of oxygen and water by CAT (Ullah et al., 2019).

In the present finding, SOD activity increased significantly in gills, liver and kidney tissues of Clarias gariepinus at higher concentrations compared with control samples. The increased in SOD activity could be associated with immediate response to the production of superoxide anions which SOD converts the radicals to $\mathrm{H}_{2} \mathrm{O}_{2}$ (Mandeep and Jindal, 2017). The elevated level of SOD activity observed in present finding revealed that paraquat induced adaptive response and it is scavenging the overproduction of superoxide ions under the oxidative stress (Mandeep and Jindal, 2017). Therefore, an increased in SOD activity indicates that there is oxygen radical generation which stimulates the overproduction of SOD activity to an extent exceeding the level of superoxide anions thereby inactivating the radicals (Inyang et al., 2018). SOD activity revealed an increased in the exposed fish tissues 
with an increase in the herbicide concentration. The increase in SOD activity could be due to the response of the fish tissues to antioxidant enzymes system caused by the presence of pesticide in the experimental water as reported by Akinwande et al. (2018). SOD scavenge superoxide radicals that served as vital agent of oxygen toxicity thereby protecting cells against the oxidative stress (Naheed, 2011). The accelerated SOD activity obtained in the exposed fish tissues may perhaps originate from low production of superoxide radicals within the cells/tissues, leading to high SOD activity in its effort to convert the radicals to $\mathrm{H}_{2} \mathrm{O}_{2}$ as reported by Ezenwosu et al. (2020). The increase in SOD activity in the fish tissues showed that the enzyme was able to overwhelm the superoxide radicals which are the most dangerous of all the free radicals as reported by Akhiromen and Ogbonne (2018). Antioxidant activities were reported to increase or decrease under toxin stress depending on the intensity of the stress, susceptibility of the exposed organisms leading to overproduction of superoxide radicals (Ullah et al., 2019). From the present investigation, increased in SOD activity in the treated fish compared with the control inferred that various metabolic responses in the exposed fish tissues led to the inhibition in the radicals as reported by Aghoghovwia and Izah (2018). The antioxidant enzymes fluctuate by the exposure to herbicide, interact basically with the cellular components, resulting in accelerated enzyme activity causing a decrease in the production of reactive oxygen species and other free radicals (Inyang et al., 2018). The increase in SOD activities in the highest concentrations might have reflected a cellular oxidative stress due to exposure to the herbicides. Similar observations were made on the effect of herbicides on C. gariepinus exposed to Glyphosate and Paraquat by Ayanda et al. (2018) and O. niloticus to Paraquat Dichloride by Akinsorotan et al. (2019).

Catalase is an antioxidant enzyme found largely in the peroxisomes where it stimulate in getting rid of hydrogen peroxide, which is metabolized to oxygen and water (Wapa et al., 2013). In the present study, Higher CAT activity obtained in gills, kidney and liver tissues compared with control showed a fluctuating trend throughout the acute exposure with an increase at the highest concentration. This might be explained due to the influx of CAT activity inhibiting the superioxide radicals and capacity to set up adequate compensation in presence of toxicant as reported by (Moreno et al., 2014).

An increase in CAT activity in the exposed fish tissues to paraquat could be due to the herbicide-mediated oxi-reduction production leading to inactivation of the radicals as reported by (Jin et al., 2015). The elevated CAT activity in the paraquat exposed tissues could be explained as an adaptive response of the fish to counter superioxide radicals or due to response to an increased oxygen consumption leading to high potential for $\mathrm{H}_{2} \mathrm{O}_{2}$ production as reported by Bibi et al. (2014). A similar increase in CAT activity was reported by Achuba et al. (2014) in the liver of Heteroclarias exposed to pollutants which was attributed to the adaptive and protective roles of the biomolecule enzymes against oxidative stress induced by the herbicides. The variation in CAT activity recorded among the tissues might be due to the rate of free radicals generation, proximity to external environment, immunity level and potential mobility into the varying exposed tissues as reported by (Oruc, 2010); who reported that detoxification system of the gills is not as robust as that of liver and kidney thus, increases its vulnerability towards ROS.

Glutathione Transferase is among the vital isoenzymes protecting cells/tissues against oxidative stress and catalyzing superoxide radicals (Achuba et al., 2014). GST is a vital phase II biotransformation enzyme, used as bioindicator of exposure to aquatic contaminants (Doherty et al., 2010). In the present finding, there was an increase in GST activity in gills, 
liver and kidneys of $C$. gariepinus in the highest concentration when compared to the control sample. The increased GST activity might be due to its effort to detoxify herbicide effect because GST combine with GSH-group to the herbicide or its metabolites, making them more hydrophilic within the cellular compartment (Annett et al., 2014). Higher GST activity was also examined by $\mathrm{Li}$ et al. (2016) in pearl mullet and in liver and gills of Japanese medaka exposed to BPA. Increased GST activity was more pronounced in gills tissues than in the liver and kidney tissues. The Increase could be due to the generation of a defensive mechanism to counteract the effects of the herbicide, indicating the potential of a strong protection against its toxicity as reported by (Mandeeb and Jandal, 2017).

\section{CONCLUSION AND RECOMMENDATIONS}

It was revealed that behavioral and oxidative stress enzymes activity were at higher concentrations and time-dependent. Behavioral alterations are biomarkers of herbicide effect on the exposed fish. Paraquat displayed toxic effect as it subjected the fish to varying physiological and oxidative stress alterations. Hence, the continuous application of the synthetic herbicide for agricultural purposes could adversely affect non-target aquatic biota. It is therefore recommended that appropriate authority should minimize the indiscriminate use of synthetic chemical due to their impact on aquatic biota such as fish in order to reduce its potential risk to consumers.

\section{REFERENCES}

Achuba, F.I., Ebokaiwe, P. and Peretiemo-Clarke, B.O. (2014). Effect of environmental pollution on oxidative stress in catfish (Clarias heterobranchus). International Journal of Enviromental Monitoring and Analysis, 2(6): 297-301.

Ada, F. B., Ekpenyong, E. and Ayotunde, E. O. (2012). Haematological, biological and behavioural changes in Oreochromis niloticus (Linne 1757) juveniles exposed to Paraquat herbicide. Journal of Enviromental Chemistry and Ecotoxicology, 4: 64- 74.

Aghoghovwia, O.A., and Izah, S.C. (2018). Acute toxicity of Paraquat dichloride based herbicide against Heterobranchus bidorsalis fingerlings. EC Agriculture, 4(2): 128-132.

Akinwande, A.A., Abdulkadiri, J.O. and Adesina, B.T. (2016). Oxidative Stress and Antioxidant Response in the Giant African Catfish (Heterobranchus bidorsalis Geoffroy SaintHilaire, 1809) under Chronic Paraquat Exposure. Nigerian Journal of Fisheries and Aquaculture, 4(2): 30 - 37.

Akinrotimi, O.A., Orlu, E.E., Gabriel, U.U. (2013) Haematological Responses of Tilapia guineensis treated with industrial effluents. Applied Ecology and Environmental Science, 1(1):10-13.

Akinsorotan, A.M. (2015). Histological Studies of African Catfish (Clarias gariepinus) Exposed to Varying Concentrations of Dizensate (Glyphosate: N-phosphonomethyl glycine). Ph.D Thesis.Delta State University, Abraka-Nigeria. P132.

Annett, R; Hamid, R. H and Alice, H. (2014). Impact of glyphosate and glyphosate-based herbicides on the freshwater environment. Journal of Applied Toxicology, 34(1):458-567.

Ani, L. C., Nwamba, H. O., Ejilibe, C. O and Nwani, C. D. (2017). Acute Toxicity of Glyphosate-Based Herbicide Glycot on Juvenile African Cat Fish Clarias gariepinus (Burchell 1822). Journal of Fisheries and Livestock Production, 5(3): 252-256.

Arivu, I., Muthulingam, M, and Jiyavudeen, M. (2016).Toxicity of paraquat on freshwater fingerlings of Labeo rohita (Hamilton). International Journal of Scientific \& Engineering Research, 7(10): 1965 - 1971.

Ayanda, O.I., Oniye, S. J., Auta, J and Ajibola, V.O. (2015). Acute toxicity of glyphosate and paraquat to the African catfish (Clarias gariepinus, Teugels 1986) using some biochemical indicators. Tropical Zoology, 28(1): 152162. 
Ayanda, I.O., G.I. Olasehinde and A.A. Ajayi, (2018). Toxicity of sublethal concentrations of glyphosate and paraquat herbicide in the African catfish (Clarias gariepinus). International Journal of Agriculture and Biology, 20(1): 1359-1364.

Babatunde, M.M., and Oladimeji A.A. (2014). Comparative study of Acute toxicity of Paraquat and Galex to Oreochromis niloticus. International Journal of Advanced Scientific and Technical Research, 3(4): 437 - 444

Banaee, M., Davoodi M.H and Zoheiri F. (2013). Histopathological changes induced by paraquat on some tissues of gourami fish (Trichogaster trichopterus). Open Vet J. 3(1): 36-42.

Bartosz, B; Mateusz, J; and Małgorzata, W. (2018) Physiological and Histological effects of herbicides in fish. Annals of Warsaw University of Life Sciences, Animal Science, 57 (3): 207-217.

Durackova, Z. (2014). "Free radicals and antioxidants for non-experts," In Systems Biology of Free radicals and Antioxidants, Springer, Berlin, Germany. 3-38.

Edori, O. S., Edori, E. S and Okpara, K. E. (2013). Chronic toxicity of Paraquat on liver and Gill electrolyte in the catfish Clarias gariepinus. Journal of Environmental Science and Technology, 7(1): 1-4.

Eizadi-Mood, N., Sabzghabaee, A. M and Badri, S. S. (2011). Paraquat Poisoning: What the Acute Care Physician Needs to Know? J. Isfahan Med. School, 29(1): 997-1006.

Ezenwosu, S. U., Emmanuel, I. N., Gregory, E. Odo., Ogonna, C. A., Obiageli, C. E., Gladys, U. O and John, F. E. (2020). Lambda-Cyhalothrin induced hepato-nephro toxicity potentials and post treatment recovery in Clarias garipinus. African Journal of Biochemistry Research, 14(1):18-26.

Ezike, C. O; Felix, O. E; Nicholas, C. U and Godwin, E. O. (2019). Haematology, Oxidative Stress and Micronuclei Frequency of Clarias gariepinus Exposed to Glyphosate based Herbicide Glycot GBHG. International Journal of Advanced Fisheries and Aquatic Science, 4(1): 106-121.

FAO/WHO, (2018). Pesticide residues in food 2018 Joint FAO/WHO Meeting on Pesticide Residues. Pp. 234-256.

Fayinminmu, O. O; Tijjani, S. O and Fadina, O. O (2017). Toxicity Assessment of Sub Lethal Doses of Chlorpyrifos on the Kidney and Liver Organs of Male Wistar Rats. International Journal of Biochemistry Research and Review, 17(3):1-15.

Glusczak, L., V.L. Loro, A. Pretto, B.S. Moraes, A. Raabe, M.F. Duarte, M.B. da Fonseca, C.C. de Menezes and D.M. de Sousa Valladao, 2011. Acute Exposure to Glyphosate Herbicide Affects Oxidative Parameters in Piava (Leporinus obtusidens). Archive of Environmental Contamination and Toxicology, 61(1): 624630.

Inyang, I.R., Ayogoi, T.A., and Izah, S.C. (2018). Effect of lindane on some selected electrolytes and metabolites of Clarias gariepinus (juveniles). Advances in Plants and Agricultural Research, 8(5):394-397.

Joseph, K. S and Kafilat, A. B. (2012). Toxicological Effects of Lead and Zinc on the Antioxidant Enzyme Activities of Post Juvenile Clarias gariepinus. Resources and Environment, 2(1): 21-26.

Jin, Y., Liu, Z and Peng, T. (2015). The toxicity of chlorpyrifos on the early life stage of zebrafish: A survey on the endpoints at development, locomotor behavior, oxidative stress and immunotoxicity. Fish Shellfish Immunology, 43(2):405-414.

Ladipo, M.K. (2011). Acute Toxicity, Behavioural Changes and Histopathological Effect of Paraquat Dichloride on Tissues of Catfish (Clarias gariepinus). International Journal of Biology, 3(2): $67-74$. 
Mandeep and Rajinder J. (2017). Oxidative stress response in liver, kidney and gills of ctenopharyngodon idellus (cuvier \& valenciennes) exposed to chlorpyrifos. MOJ Biology and Medicine, 1(4):103-112.

Modesto, K.A and Martinez, C.B.R. (2010). Effects of Roundup Transorb on fish: Hematology, antioxidant defenses and acetylcholinesterase activity. Chemosphere, 81(1): 781- 787.

Moreno, N.C., Sofia, S.H and Martinez, C. B. R. (2014). Genotoxic effects of the herbicide Roundup Transorb and its active ingredient glyphosate on the fish Prochilodus lineatus. Environ. Toxicol. Pharmacol., 37(1): 448454.

Nahed, S. G. (2011). Oxidative Stress and Antioxidant Enzymes in Oreochromis niloticus as Biomarkers of Exposure to Crude oil Pollution. International Journal of Environmental Science and Engineering (Ijese), 1(1): 49-58.

Nwani, C.D., N.S. Nagpure, R. Kumar, B. Kushwaha and W.S. Lakra, 2013. DNA damage and oxidative stress modulatory effects of glyphosate-based herbicide in freshwater fish, Channa punctatus. Environ. Toxicol. Pharmacol., 36(1): 539 - 547.

Nwani, C.D., Ekwueme H.I., Ejere, V.C., Onyeke, C.C., Chukwuka, C.O., Peace, O.N. and Nwadinigwe, A.O. (2015). Physiological effects of Paraquat in juvenile African catfish Clarias gariepinus (Burchell, 1822). Journal of Coastal Life Medicine, 3(1):35-43.

OECD (2014), Test No. 487: In Vitro Mammalian Cell Micronucleus Test, OECD Guidelines for the Testing of Chemicals, Section 4, OECD Publishing, Paris.

Ogamba, E.N, Inyang, I.R. and Azuma, I.K. (2014). Effect of paraquat dichloride on some metabolic and enzyme parameters of Clarias gariepinus. Current Research Journal of Biological Science, 3(1):186- 190.

Olele, N. F and Zelibe, S.A. (2013) Acute toxicity and behavioural changes on African catfish (Clarias gariepinus) exposed to dizensate (glyphosate herbicide). International Journal of Scientific and Engineering Research, 4(1): 1-5.

Oluwatosin, A.A; Olajumoke, O.N; John, A.A and Jacob, K.A. (2016). Induction of Oxidative Stress in Clarias gariepinus from Eleyele River in Nigeria. Advances in Environmental Research, 5(3): 179-187.

Omoniyi, I.T., Kazeem, L.A and Samuel O.O. (2013). Lethal Effects Of 2,2-Dichlorovinyl Dimethyl Phosphate .Ddvp $\square$ On Fingerling And Juvenile Clarias gariepinus .Burchell, 1822 Croation Journal of Fisheries, 71(1):19-24.

Oruc, E. O. (2010). Oxidative stress, steroid hormone concentrations and acetylcholinesterase activity in Oreochromis niloticus exposed to chlorpyrifos. Pest Biochem Physiol., 96(1):160-166.

Rakesh, S. and Kumar, S.V (2019). Acute toxicity and behavioural responses in Clarias batrachus (Linnaeus) exposed to herbicide pretilachlor. Heliyon, 5(1): 2405-8440.

Ullah, S., Zhongqiu L., Amina, Z., Muhammad, Z. U. A., Mirza, M. F. A. B. (2019). Biomarkers of pyrethroid toxicity in fish. Environmental Chemistry Letters, 1(1): 1-28.

Yang, C., Whasun, L and Gwonhwa, S. (2020). Mediation of oxidative stress toxicity induced by pyrethroid pesticides in fish. Comparative Biochemistry and Physiology, Part C, 234(1): 1-11. 